\begin{tabular}{c} 
Volume and Issues Obtainable at Center for Sustainability Research and Consultancy \\
Journal of Accounting and Finance in Emerging Economies \\
ISSN: 2519-0318 \& ISSN (E): 2518-8488 \\
Volume 7: Issue 3 September 2021 \\
CSRᄃ \\
Journal homepage: www.publishing.globalcsrc.org/jafee \\
\hline
\end{tabular}

\title{
A Comparative Study of Southern Punjab and Balochistan SMEs Success vs Failure Factors
}

\author{
*Khawar Naheed, Department of Commerce, BZU. Multan, Pakistan \\ Shakeel Ahmad, PhD Scholar Management Science IUB, Pakistan \\ Farheen Zahra Hussain, Department of Commerce, BZU. Multan, Pakistan \\ Muhammad Sadiq Shahid, Associate Professor, Department of Commerce, BZU, Multan, \\ Pakistan
}

*Corresponding author's email: khawarnaheed @bzu.edu.pk

\begin{tabular}{l}
\hline ARTICLE DETAILS \\
\hline History \\
Revised format: Aug 2021 \\
Available Online: Sep 2021 \\
\hline
\end{tabular}

Keywords

Success or Failure,

Southern Punjab,

Balochistan, Small Medium

Enterprises (SME's),

Lussier Model.

JEL Classification

$M 1, M 2$

\section{ABSTRACT}

Purpose: SME's in Pakistan like developed economies play crucial role in the economic development and sustainability as long as entrepreneurs should be mindful about SME's success and failure factors. In the extant literature, particularly in Pakistan, there is a lack of studies that have been empirically examined the comparative factors of Southern Punjab and Balochistan this setting particularly in Pakistan. The current study has focused on the comparative analysis of success or failure of Southern Punjab and Balochistan SME's. The purpose of paper is to examine the aspects of SMEs that are central to their success/failure functioning in both areas of Pakistan.

Design/Methodology/Approach: Data was collected through a questionnaire using the Lussier's Model of success or failure factors among the owners of successful and unsuccessful SMEs. The researchers collected 200 questionnaires from SMEs. Data was analyzed by using the logistic regression technique. Findings: Results of the current study showed that management experience, planning, professional advice, staff, product and services, marketing, and age are important for the viability and success of SME's operating in Southern Punjab. In Balochistan, management experience, planning, professional advice, education, marketing are significant for the success/failure of SME's.

Implications/Originality/Value: Thus, this study adds value to the knowledge to enhance understanding in "why some businesses succeed and others fail" by using Lussier's Model. The results of the study assist policymakers in developing the programs that enhance the SME's promotion, establishment, and development.

(C) 2021, The authors, under a Creative Commons AttributionNonCommercial 4.0

Recommended citation: Naheed, K., Ahmad, S., Hussain, F. Z. and Shahid, M. S. (2021). A Comparative Study of Southern Punjab and Balochistan SMEs Success vs Failure Factors. Journal of Accounting and Finance in Emerging Economies, 7 (3), 767-775. 


\section{Introduction}

Economists, experts and academicians proved that SMEs help economies raise scarcity; create employment, increase growth (Soltanian, Zailani, Iranmanesh, \& Aziz 2016; Tarek, Zouhayer, \& Adel 2019), encourage improvement and improve R\&D (Ejaz, 2012). SMEs help economies in job creation, create social strength and increase access to capital (Peter et al., 2018). The study of Tambunan (2019) underlined that more that more than 90\% of SMEs in developing countries, particularly more than $90 \%$ Pakistani small enterprises are engaged in the development of SMEs. These SMEs were supported by SMEDA ${ }^{1}$ in many areas of industry and trade (Ali, Ahmed, Mirani, Khan 2021). It is highlighted in the previous study that failing ration SME's is very high (Hyder \& Lussier, 2016). Moreover, the failure rate of SME's can be minimized with the many factors that are associated with the owners' ability to efficient utilization of resources and its skills and entrepreneurial characteristics.

It is also well documented that the formation and creation of SME's are crucial for the growth, success and sustainability of this sector in Pakistan. Reardon et al., (2021) recommended that it is necessary to focus on the development of SMEs in Pakistan. Therefore, it is crucial to focus on the establishment of SME's and to reduce the phenomenon of their failure. The objective of this study is to focus on highlighting the success or failure factors of Southern Punjab and Balochistan.

\section{Literature Review}

Success or failure is not an action rather the result of several factors that can influence SME's competence to persistence, growth, and prosperity (Antoniuk et al., 2018). SME's owners like other organizations may receive precautions that should alarmed them about a business problem or a conflict that need to be highlighted (Salomo et al., 2008). Like success, failure is the product of the events that comes from the process that an entrepreneur strives for (Krstić \& Radulović, 2015). From this point of view, an entrepreneur receives a cautionary signal that warns him/her about the business problematic situation that needs a solution. However, the frequent indications subsequent from the problematic situation might befall, till an enterprise is enforced to close. In this study, failure is defined as proprietor of enterprise close his/her business due to suffering loss or not earning a profit.

The current study used Lussier (1995) SME's success/failure prediction model. The fifteen factors' variables were examined to determine the reason for the business's success vs failure of SME's operating in Southern Punjab and Balochistan. These factors are: "capital, industry experience, record keeping and financial control, planning, management experience, education, professional advisors, staffing, age of the owner, product/service timing, marketing skills, partners, parents and economic timing". To conduct further research on SMEs for the development of society and economy was highlighted by the study of Arasti et al. (2012).

Researchers argued that it is difficult to point out success or failure on SME's (2000). Both defined as "success as the company's ability to survive" (Stefanovic et al. 2010). The study of Hussain and Windsperger, (2010) that entrepreneur's "previous experience, knowledge, social skills, capital, and working hard are essential for success" The study of Benzing et al., (2009) divided the success factors into psychological and personal (skills, knowledge and training) and environment. Psychological factors include independence, innovativeness, attitude towards risk and a competitive nature. Personal factors consisted of skills includes entrepreneur's ability to manage work stress and self enhancement. The environmental conditions depend upon sufficient governmental support, access to the capital and support of family and friends (Mayr, Mitter, Kücher, 2021).

${ }^{1}$ Small and Medium Enterprise Authority (SMEDA) 
The factors that lead to the failure of SMEs are ignored in the existing literature. However, there are studies that have discussed about the failures of SMEs. The study of Bezing et al (2009) explained that the agile environment (political and economic), tax system, and inappropriate rules are the common reasons of failure in developing economies. Asian Development Bank in (2005) reported the constraints faced by the SMEs in their growth; credit limit, high cost of credit and financing, high compliance cost, poor infrastructure, poor skill and training, market transaction cost, and legal requirements. The study of Hussain et al. (2010) explained that lack of financial support and access to capital is the highest rating failure factors.

The current study has selected the most widely used prediction Model of Lussier (1995) to measure success or failure of SME's. Previous studies have validated the model, particularly in comparative analysis. Lussier (19915) prediction model examined the ability of success or failure factors examined and tested in prior studies (Baidon et al. 2018; Gyimah et al. 2020; Lussier \& Halabi 2010). The following fifteen factors tested to measure success or failure of SMEs by previous studies: "Capital, Record keeping and financial control, Industry experience, Management experience, Planning, Professional advisors, Education, Staffing, Product/ Service timing, Economic timing, Age, Partners, Parents, Minority, Marketing”.

Lussier \& Halabi (2010) inform about the consistency of financial models that used the financial data to predict the financial performance of SME's that were used by the extant studies to measure their financial performance. These financial models were incapable to perfectly predict the performance of new SME's. The dependable financial data are dependent on financial policies and unrealistic to foresee success/failure (Gayimah et al., 2020). The reasons of using prediction Model proclaimed that subjective factors perfectly forecast the success/failure of SME's particularly for new SMEs without previous financial information.

One of the important intentions of selecting a prediction-based model is model flexibility. Lussier \& Halabi (2010) suggested other researcher to consider a prediction model to measure the success/failure of SME's operating in other economies because their demographic and cultural factors. Following the recommendation, the current study measure the success/failure of SME's operating in Southernern Punjab and Baluchistan.

\section{Methodology}

To fulfill the objective of the current study, the information was collected from the areas of Southern Punjab and Balochistan. The researcher has taken the responses of the set of questionnaires through the various categories of respondents that belonged to different sizes of business gender, education and areas. The close ended questionnaire was developed. The population of this study was successful or failed SME's. Successful owners are explained as those operating their business at least more than 3 years and failed owners are those who cannot successfully run their business.

Using Lussier (1995) prediction model to measure success or failure variables of SMEs operating in both provinces. In this study, the variables in the prediction model were already inferred in the literature as contributing causes of success/failure in SMEs through statistical testing in previous studies. Each one of the independent variables in the model is tested to determine if they have an effect or not on the dependent variables (success and/or failure) in the context of SMEs in Southern Punjab and Balochistan.

Like Lussier (1995), suggested using failed or successful matched SMEs to run their business for at least three years. The researcher approached to the Chamber of Commerce and SME's offices established in Southern Punjab and Balochistan. 
The current study used convenient sampling approach. The researcher personally visited the successful and failure SMEs owners in South Punjab and Balochistan. Data was collected from the SMEs operating in Southern Punjab and Balochistan. The data were analyzed from the sample of 100 successful or failed SME's operating their business in South Punjab and Balochistan. The well-established Lussier's Success/Failure model was adopted to measure the variables of the current study.

\section{Logistic Regression}

The data of SME's success/failure factors were analyzed through the most widely used Logistic Regression method (Cooper et al. 1994). The multiple logistic regression analysis method help to choose the finest blend of success/failure factors "reduced model".

Cox (1958) developed a statistical model that is widely used called the logistic regression model. The logistic regression was estimating the relation of multiple parameters. Therefore, this multivariate regression describes that the paradox exists between the dependent variables and independent variables.

According to Scherr, (1989), the appropriate test for the overall significance of the model is the goodness of fit of the model measured by the $-2 \log$-likelihood, (LL) statistic. The (LL) compares the actual model to a perfect model in which all cases would be correctly classified.

The results of logistic regression are always categorical. The binary logistic regression model has multinomial logit means to have more than two dependent variables and the value of these corresponding probability labeled as 1 and 0 . The other perspective is helpful to analysis the discrimination of variables; hence it is appropriate to use the interpretation of present study. Further, the logistic regression can be applied on variables "binominal, ordinal or multinomial" therefore, dependent variable must be dichotomous. This study used logistic regression to estimate factors used in the following equation.

SUC $=$

$\beta_{0}+\beta_{1}$ capti $+\beta_{2}$ inexi $+\beta_{3}$ maexi $+\beta_{4}$ plani $+\beta_{5}$ pradi $+\beta_{6}$ stafi $+\beta_{7}$ pstii $+\beta_{8}$ ectii $+\beta_{9}$ mrkt $+\beta_{10}$ pent $\mathrm{i}+\beta_{11}$ educi $+\beta_{12}$ age $+\beta_{13}$ parti $+\beta_{14}$ rkfci $+\beta_{15}$ miori $+\mu_{i}$

$\mathrm{FAL}=\beta_{0}+\beta_{1}$ capti $+\beta_{2}$ inexi $+\beta_{3}$ maexi $+\beta_{4}$ plani $+\beta_{5}$ pradi $+\beta_{6}$ stafi $+\beta_{7}$ pstii $+\beta_{8}$ ectii $+\beta_{9}$ mrkt + $\beta_{10}$ penti $+\beta_{11}$ educi $+\beta_{12}$ agei $+\beta_{13}$ parti $+\beta_{14}$ rkfci $+\beta_{15}$ miori $+\mu_{i}$

Where SUC/FAL=dummy for success/failure variables and a set of independent variables "capital (capt), industry experience (inex), management experience (maex), planning (plan), professional advisor (prad), staffing (staf), product/services timing (psti), economic timing (ecti), marketing (mrkt), parents (pent), education (educ), age (age), partners (part), record keeping financial control (rkfc), minority (mior)" (Lussier, 1995).

The concept "success/failure" implied a sole factor that can have influence on "success and/or failure", not certainly either or. Furthermore, a factor can influence on "success, on failure, or both". With the variable "Capital" (a variable in this study) mean that for some, this variable is a "success" factor while for others this variable contribute to "failure" due to lack of capital, it can be either way. In this case the null hypothesis would be rejected in favor of the alternative hypothesis. There is a null and alternative hypothesis for 15 independent variables in this study.

\section{Analysis}

The variables under consideration are: for example, capital "money invested to start the business was sufficient". Previous experience "I had propose experience of this business for starting it". , "I 
had previously management experience" and so on. Table 1 showed overall result of the current study.

Table 01: Variables in the Equation

\begin{tabular}{|l|c|c|c|c|c|c|}
\hline Step 1 & B & S.E. & Wald & df & Sig. & Exp(B) \\
\hline "Money invested to start the business was sufficient" & 2.755 & 6350 & 0.000 & 1 & 1.000 & 0.0640 \\
\hline "I had propose experience of this business for starting it" & 0.958 & 8832. & 0.000 & 1 & 1.000 & 0.384 \\
\hline "I had previously management experience". & 14.63 & 8324. & 0.000 & 1 & 0.999 & 646.56 \\
\hline $\begin{array}{l}\text { "Before starting the business properly planned that } \\
\text { business" }\end{array}$ & 0.008 & 13868. & 0.000 & 1 & 1.000 & 0.992 \\
\hline "I got professional advice to start that business" & 0.263 & 7200. & .000 & 1 & 1.000 & 1.300 \\
\hline "My employees in that business active \& reliable" & 5.782 & 6750 & 0.000 & 1 & 0.999 & 324.54 \\
\hline "I have been introducing new product and services" & 1.828 & 7436. & 0.000 & 1 & 1.000 & 6.222 \\
\hline $\begin{array}{l}\text { "I have been actively changing decisions according to } \\
\text { market situation". }\end{array}$ & 4.595 & 9014. & 0.000 & 1 & 1.000 & 99.007 \\
\hline "I have marketing skills". & 6.730 & 15533 & 0.000 & 1 & 1.000 & 837.94 \\
\hline "Did your parents have similar business?" & 2.774 & 24793 & 0.000 & 1 & 1.000 & 16.015 \\
\hline "Do you think education play important role in business" & 11.790 & 42785 & 0.000 & 1 & 1.000 & .000 \\
\hline "Do you think owner's age also impact on business?" & 20.490 & 20146 & 0.000 & 1 & 0.999 & 0.000 \\
\hline "Staff role is very important to run a business." & 0.5370 & 43743 & 0.000 & 1 & 1.000 & 0.5840 \\
\hline $\begin{array}{l}\text { "Financial control record sufficient for success and } \\
\text { failure." }\end{array}$ & 21.030 & 18817 & 0.000 & 1 & 0.999 & 912. \\
\hline "Minority has participation in business." & -6.564 & 21363 & .000 & 1 & 1.000 & .0010 \\
\hline Constant & -66.25 & 27188 & .000 & 1 & 0.998 & .0000 \\
\hline
\end{tabular}

In Table 02 showed that $\mathrm{p}$ values greater than 0.05 showed insignificant effect of the factor on success/failure while p value less than .05 value $(<0.05)$ showed significant effect of a particular factor on success/failure of SME's. In Table 02 the $p$ value greater than " $<0.05$ " indicated that there is need to change the significance of result and predict that there is need of change. However, capital and parents values are greater than 0.05 that showed the insignificant effect of these two variables on the success/failure of SME's. Result showed that "industry and management experience, planning, professional advice, staff, product and services, economic timing, marketing, education, age, partners, and record keeping and financial control" are significant factors that effect on success/failure of SME's in Southern Punjab and Balochistan.

Table No: 2 Overall Results of SUCCESS/ failure Predicted Model

\begin{tabular}{|l|l|l|l|}
\hline Variable & Coeff. & Std. Error & Prob. \\
\hline Q1(capital) & 0.010 & 0.0122 & 0.4108 \\
\hline Q2(industry experience ) & 0.0676 & 0.0218 & 0.0182 \\
\hline Q3 (management experience) & 0.0686 & 0.0288 & 0.0192 \\
\hline Q4(planning) & 0.1476 & 0.0304 & 0.0000 \\
\hline Q5(professional advise) & 0.0372 & 0.0137 & 0.0066 \\
\hline Q6(staff) & 0.1172 & 0.0280 & 0.0000 \\
\hline Q7(product \& services) & 0.0353 & 0.0135 & 0.0089 \\
\hline Q8(economic timing) & 0.0621 & 0.0243 & 0.0106 \\
\hline Q9 (marketing) & 0.0606 & 0.0208 & 0.0172 \\
\hline Q10(parents) & 0.0195 & 0.0250 & 0.4364 \\
\hline Q11(education) & 0.2303 & 0.0833 & 0.0057 \\
\hline Q12(age) & 0.1789 & 0.0886 & 0.0436 \\
\hline Q13 (partners) & 0.0616 & 0.0208 & 0.0162 \\
\hline Q14(record keeping \& financial control) & 0.3749 & 0.1298 & 0.0039 \\
\hline Constant & 0.1732 & 0.024149 & 0.0000 \\
\hline
\end{tabular}

Table 3 showed the results of success/failure factors of both Southern Punjab and Balochistan SME's. The results of SME's operating in Southern Punjab are: "management experience, planning, professional advice, staff, product and services, marketing, and age" were the significant and positive association with success/failure SME's as the $\mathrm{p}$ values are $<.05$. However the factors, namely, "capital, industry experience, parents, education, partners, and record keeping and 
financial control" were not significant factors because the p values are greater .05 that can contribute to success/failure of Southern Punjab SME's.

The factors that are significant towards the success/failure of SME's in Balochistan are: "management experience, planning, professional advice, education, marketing" while "capital, industry experience, staff, product and services, parents, education, age, partners and record keeping and financial control" are insignificant factors as the $\mathrm{p}$ values are greater than .05 .

Table No: 3: Dependent Variable: Success Vs Failure

\begin{tabular}{|l|c|c|c|c|c|c|}
\hline & \multicolumn{3}{|c|}{ Balochistan } & \multicolumn{3}{c|}{ (Southern Punjab) } \\
\hline Variable & Coeff. & Std. Error & Prob. & Coeff. & Std. Error & Prob. \\
\hline Q1 (capital) & 0.0037 & 0.0093 & 0.689 & 0.38996 & 0.41099 & 0.3440 \\
\hline Q2 (industry experience ) & 0.0125 & 0.0104 & 0.228 & 0.18608 & 0.13290 & 0.1631 \\
\hline Q3(management experience) & 0.0510 & 0.0158 & 0.002 & 0.32153 & 0.01522 & 0.0000 \\
\hline Q4 (planning) & 0.5300 & 0.0158 & 0.015 & 0.35330 & 0.01422 & 0.0000 \\
\hline Q5 (professional advise) & 0.4850 & 0.0158 & 0.015 & 0.33533 & 0.01322 & 0.0000 \\
\hline Q6 (staff) & 0.0715 & 0.0173 & 0.000 & 0.01122 & 0.11229 & 0.9219 \\
\hline Q7 (product \& services) & 0.1832 & 0.0229 & 0.000 & 0.13293 & 0.07685 & 0.0853 \\
\hline Q8 (education) & 0.8626 & 0.0588 & 0.000 & 0.2898 & 0.11769 & 0.0147 \\
\hline Q9 (marketing) & 0.3850 & 0.0158 & 0.015 & 0.3353 & 0.01322 & 0.0000 \\
\hline Q10 (parents) & 0.0131 & 0.0178 & 0.464 & -0.2142 & 0.42535 & 0.6150 \\
\hline Q11 (education) & 0.0157 & 0.0173 & 0.364 & 0.35740 & 0.43977 & 0.4174 \\
\hline Q12 (age) & 0.1309 & 0.0194 & 0.000 & 0.58602 & 0.40757 & 0.1522 \\
\hline Q13 (Partners) & 0.0341 & 0.0188 & 0.464 & 0.21428 & 0.42535 & 0.6150 \\
\hline $\begin{array}{l}\text { Q14(record keeping } \\
\text { control) }\end{array}$ & & & & & & \\
\hline Constant & & & & & \\
\end{tabular}

\section{Discussion}

Factors that have been identified as important to the success or failure of SMEs in the two provinces (Southern Punjab and Baluchistan). The result indicated that these factors need to be focused and improved in both areas as these contributed towards the success or failure of SME's.

It describes that the management experience, planning, professional management, no of staff, product and services marketing and age are the pillars of the success of Southern Punjab SME's. The results indicated prior experience of running the business is crucial for successful business. Proper planning, appropriate, support from staff and nature and innovation and the nature of product and services leads to the growth of SME's. Southern Punjab results are supported with the result of prior studies. For instance, the result are in lined with the study conducted in Singapore, the critical success factors for SMEs were high quality staff working in the business and top management quality. Moreover, another study also found surprising result like the current study that access to finance, and good government policy as not statistically significant compared with other variables in the model (Siow et al., 2011). However, finance and economic policies, the current study also found that parent support, education, partners support and record keeping were found to be insignificant.

Moreover, in Balochistan, in addition to managerial experience, planning, professional advice, the proper education and marketing strategies of product services were found to be significant. A study conducted in the US also highlighted the role of specific plans and marketing and professional suggestions to success of the business (Marom \& Lussier, 2014). However, the current study found that education also plays important role in Balochistan SME's as compare to Southern Punjab SME's. Therefore, SMEs in Balochistan have cultural diversity, focus on education, and operates SMEs businesses with a focus on planning.

The result highlighted that there is a need to focus on staff, product and services and age in Southern 
Punjab SME's while there is need to focus on education and marketing Balochistan SME's. Overall management experience, planning, and professional advice need to be focused in both areas of SME's.

\section{Implication and Recommendation}

The result implied that SME's policy makers and government bodies should focus on arranging training sessions, conferences, and to educate the entrepreneur's about the significance of successful factors, particularly on training of staff, products, age in Southern Punjab while education and marketing strategies in Balochistan. Business owners need to make aware that focus on the factors make their business successful rather than relying on luck. This will help to decrease SME's failure rate, close up, bankruptcies and default rates. In addition, the initiatives create employment, decrease job losses, efficient planning, increase in government revenues and help towards a healthier economy. Moreover, there is a lack of entrepreneurial mentorship and in the provincial government provides a low level of support to the public to facilitate and boost up entrepreneurship in Southern Punjab and Balochistan. This initiative is also highlighted by the study of (Peter, Adegbuyi, Olokundun, Peter, Amaihian, \& Ibidunni, 2018)

Theoretically, it is quite significant research in which efforts made at the wide area of Pakistan to determine the involvement of factors in success versus failure and these are also relevant to the developing economy such as Southern Punjab and Balochistan. Hence, to develop an indigenous model of entrepreneurial success versus failure, which constitutes the comprehensive but balanced combination of micro and macro factors. Its anticipation should develop the Southern Punjab and Balochistan SME's, according to the provided model formation that will boost up SME's towards growth.

To increase the generalizability of findings, there is need to collect data from all provinces of Pakistan. In addition, a qualitative study can also be conducted to know about the success or failures' of SME's in Pakistani context and culture.

\section{Conclusion}

As small medium enterprises are a perspective to the growth of the economy. Particularly, it is the discussion related to the effect of SMEs in Southern Punjab and Balochistan. These SMEs need institutional and governmental support from a general point of view. The strength of the development of SMEs in Southern Punjab and Balochistan required proper guidelines and help. This study steps forward to guide the enterprises in a particular area of Pakistan. The prediction model has reported the result of the significant influence of success or failure factors SMEs operating in Southern Punjab and Balochistan. Results of the current study indicated that factors like management experience, planning and professional advice are the determinants of SME's in both areas. In Southern Punjab, marketing, age, no of staff and product and service are the significant factors. In Balochistan, education and marketing strategies are significant factors. Precisely, the result of the current study highlighted the success or failure factors varied across the regions because these are based on cultural and behavioral differences.

\section{References}

Ali S., Li, W., Ahmed, N., Ali Mirani, M., \& Khan, A. (2021). Examining the factors affecting SME performance: mediating role of social media adoption. Sustainability, 13(1), 75.

Antoniuk, L., Britchenko, I., Polishchuk, Y., Rudyk, N., Sybirianska, Y., \& Machashchik, P. (2018). Code of ethics for SMEs: Substantiating the necessity and willingness to implement in Ukraine. Problems and perspectives in management, 16(3), 150-162.

Arasti, Z., Zandi, F., \& Talebi, K. (2012). Exploring the effect of individual factors on business failure in Iranian new established small businesses. International Business Research, 5(4). 
Baidoun, S. D., Lussier, R. N., Burbar, M., \& Awashra, S. (2018). Prediction model of business success or failure for Palestinian small enterprises in West Bank. Journal of Entrepreneurship in Emerging Economies.

Beaver, G., \& Jennings, P. (2000). Editorial overview: Small business, entrepreneurship and enterprise development. Strategic Change, 9(7), 397.

Benzing, C., Chu., M., \& Kara, O. (2009). Entrepreneurs in Turkey: A factor analysis of motivations, success factors, and problems. Journal of Small Business Management, 47(1), 58-91.

Carter, R., \& Auken, V. (2006). Small firm bankruptcy. Journal of Small Business Management, 44(4), 493-512.

Carter, R., \& Auken, V. (2006). Small firm bankruptcy. Journal of Small Business Management, 44(4), 493-512.

Cooper, C., Gimeno-Gascon, J., \& Woo, Y. (1994). Initial human and financial capital as predictors of new venture performance. Journal of business venturing, 9(5), 371-395.

Ejaz, K. (2012). Role of high performance work systems in SMEs (Doctoral dissertation, Foundation University, Islamabad).

Gyimah, P., Appiah, O., \& Lussier, N. (2020). Success versus failure prediction model for small businesses in Ghana. Journal of African Business, 21(2), 215-234.

Hussain, D., \& Windsperger, J. (2010). Multi-unit ownership strategy in franchising: development of an integrative model. Journal of Marketing Channels, 17(1), 3-31.

Hyder, S., \& Lussier, N. (2016). Why businesses succeed or fail: a study on small businesses in Pakistan. Journal of Entrepreneurship in Emerging Economies.

Krstić, G., \& Radulović, B. (2015). Shadow Economy in Business and Entrepreneurial Sectors. u: G. Krstić, F. Schneider [ur.] Formalizing the Shadow Economy in Serbia: Policy Measures and Growth Effects.

Lussier, N. (1995). A non-financial business success versus failure prediction model for young firms. Journal of Small Business Management, 33(1), 8-20

Lussier, N. (2001).A cross-national prediction model for business success. Journal of Small Business Management, 39(3), 228-239.

Lussier, N. \& Halabi, E. (2010). A three-country comparison of the business success versus failure prediction model. Journal of Small Business Management, 48(3), 360-377.

Marom, S. \& Lussier, N. (2014). A business success versus failure prediction model for small businesses in Israel", Business and Economic Research, 4(2), 63-81.

OECD (2004). Promoting entrepreneurship and innovative SME's in a global economy: towards a more responsible and inclusive globalisation. Second OECD conference of ministers responsible for small and medium-sized enterprises (SMEs), available at: www.oecd.org/cfe/smes/31919278.pdf (accessed 2 May 2019)

Peter, F., Adegbuyi, O., Olokundun, M., Peter, O., Amaihian, B., \& Ibidunni, S. (2018). Government financial support and financial performance of SMEs. Academy of Strategic Management Journal, 17.

Reardon, T., Liverpool-Tasie, O., \& Minten, B. (2021). Quiet Revolution by SMEs in the midstream of value chains in developing regions: wholesale markets, wholesalers, logistics, and processing. Food Security, 1-18.

Salomo, S., Brinckmann, J., \& Talke, K. (2008). Functional Management Competence and Growth of Young Technology-Based Firms. Creativity and Innovation Management, 17(3), 186203.

Scherr, C. (1989). Causality, Regression, Discriminant Analysis, and Research on Failure," Akron Business and Economic Review, 8-20.

Seow, N., Choong, O., \& Ramayah, T. (2021). Small and medium-size enterprises' business performance in tourism industry: the mediating role of innovative practice and moderating role of government support. Asian Journal of Technology Innovation, 29(2), 283-303. 
Soltanian, M., Zailani, S., Iranmanesh, M., \& Aziz, A. (2016). Motivations of SME entrepreneurs to become halalpreneurs. Journal of Science and Technology Policy Management.

Stefan Mayr, Christine Mitter, Alexander Kücher \& Christine Duller (2021) Entrepreneur characteristics and differences in reasons for business failure: evidence from bankrupt Austrian SMEs, Journal of Small Business \& Entrepreneurship, 33:5, 539-558.

Stefanovic, I., Prokic, S., \& Rankovic, L. (2010). Motivational and success factors of entrepreneurs: the evidence from a developing country. Zbornik radova Ekonomskog fakulteta u Rijeci: časopis za ekonomsku teoriju i praksu, 28(2), 251-269.

Tambunan, T. (2019). Recent evidence of the development of micro, small and medium enterprises in Indonesia. Journal of Global Entrepreneurship Research, 9(1), 1-15.

Tarek, H., Zouhayer, M., \& Adel, G. (2019). Entrepreneurial competitive intelligence between Uppsala model and born global theories in the case of North African SMEs. Journal of the Knowledge Economy, 10(2), 734-755.

Teng, S., Bhatia, S., \& Anwar, S. (2011). A success versus failure prediction model for small businesses in Singapore. American Journal of Business. 